\title{
APLIKASI PEMBELAJARAN DASAR BAHASA INGGRIS UNTUK ANAK USIA 5-12 TAHUN BERBASIS PLATFOM ANDROID
}

\author{
Taryana Suryana ${ }^{1}$, Sandy Septian ${ }^{2}$ \\ ${ }^{1,2}$ Teknik Informatika - Universitas Komputer Indonesia \\ Jl. Dipatiukur 112 - 114 Bandung \\ E-mail : taryanarx@email.unikom.ac.id ${ }^{1}$, sand.septian@gmail.com²
}

\begin{abstract}
ABSTRAK
Proses pembelajaran khususnya untuk anak tidaklah mudah karena sebagian besar sifat anak belum bisa fokus pada saat belajar. Kesulitan lain anak dalam belajar disebabkan karena kecenderungan pola belajar anak yang lebih suka bermain juga sangat mempengaruhi sehingga pembelajaran secara teoritis saja kurang optimal untuk pembelajaran bahasa inggris. hal tersebut mengakibatkan lamanya waktu yang dipelukan anak untuk dapat berkomunikasi menggunakan bahasa Inggris. Maka dibutuhkan media pendukung pembelajaran untuk menarik minat belajar anak agar bisa belajar secara mandiri Pembangunan aplikasi ini menggunakan metode penelitian deskriptif dan metode pendekatan sistem yang digunakan adalah metode pendekatan berorientasi objek menggunakan model UML (unifief modeling language). Pada aplikasi ayo belajar bahasa inggris berbasis android ini terdapat 6 materi pelatihan dasar kosakata bahasa Inggris mengenai warna, angka, buah, huruf, buah, hewan dan benda yang disertai latihan dan evlusai untuk mengukur pemahaman anak. Aplikasi ini didukung dengan gambar, suara dan animasi yang diharapkan dapat menarik minat belajar anak. Diharapkan dengan adanya aplikasi ayo belajar bahasa inggris berbasis android ini dapat membantu untuk meningkatkan pemahaman dan membuat anak dapat belajar mandiri, sekaligus sebagai alternatif media pembelajaran selain buku.
\end{abstract}

Kata Kunci: Pembelajaran. Android. Bahasa Inggris

\section{PENDAhUluAN}

Bahasa merupakan alat komunikasi yang penting bagi manusia. Bahasa merupakan struktur makna yang bebas dari penggunanya, sebagai tanda yang menyimpulkan suatu tujuan. Bahasa di dunia ini sangatlah beranekaragam, sehingga manusia tidak mampu untuk menguasai seluruh bahasa asing. Walaupun ingin menguasai beberapa bahasa asing, diperlukan waktu yang cukup lama untuk mempelajarinya. Salah satu kegunaan bahasa adalah untuk menyampaikan informasi, bisa berupa teks atau bahasa yang ditulis melalui gambar[1].

LIEBE (Language is Everiway Becomes Expert) adalah sebuah lembaga pendidikan in formal yang konsen di bidang pendidikan Bahasa Inggris. Seiring pesatnya kemajuan teknologi maka pola pembelajaranpun berevolusi dengan perlahan mengikuti karakter dan kondisi sikologis peserta didik. Agar terjalin sinergisitas antara intrukstur dan peserta didik dalam hal penyampaian dan penerimaan materi, namun dalam proses pembelajaran terdapat beberapa kesulitan baik dari cara segi cara mengajar yang kurang dipahami peserta didik maupun dari kesadaran belajar dari anak didik itu sendiri. Adapun alat bantu pembelajaran yang digunakan saat ini adalah berupa teks buku, fuzle dan kaset yang diputar menggunakan mini kompo.

Proses pembelajaran khususnya untuk anak tidaklah mudah karena sebagian besar sifat anak belum bisa fokus pada saat belajar. Kesulitan lain anak dalam belajar disebabkan karena kecenderungan pola belajar anak yang lebih suka bermain juga sangat mempengaruhi sehingga pembelajaran secara teoritis saja kurang optimal untuk pembelajaran bahasa inggris pada anak[2], selain itu bahasa inggris bukan bahasa yang biasa digunakan sehari-hari oleh anak maupun orang tua, sehingga mereka tidak terbiasa untuk menangkap apa yang di ucapkan oleh pengajar dan mengucapkan pelafalan dalam bahasa inggris, hal tersebut mengakibatkan lamanya waktu yang dipelukan anak untuk dapat berkomunikasi menggunakan bahasa Inggris.

Bermain merupakan sarana belajar anak. Melalui bermain anak diajak untuk bereksplorasi, menemukan memanfaatkan dan mengambil kesimpulan mengenai benda di sekitarnya. Sehingga menjadikan terobosan baru sebagai program pendidikan atau pelatihan yang dikemas dalam konsep hiburan menjadi solusi dalam proses belajar, sehingga setiap anak hampir tidak menyadari bahwa mereka sebenarnya sedang diajak untuk belajar[2]. 
Maka dibutuhkan alat bantu pembelajaran dasar Bahasa Inggris untuk anak usia 5-12 tahun yang lebih interaktif. Pada dunia pendidikan pun berkembang pemanfaatan mobile aplication. Dengan membuat mobile aplication dibidang pendidikan yaitu memberikan pembelajaran sekaligus permainan terhadap anak sebagai alat bantu pembelajaran. Aplikasi ini diharapkan diterima di kalangan pengajar dan anak-anak agar dapat menerapkan sistem belajar sambil bermain, serta kepada orangtua dalam memberikan pembelajaran di rumah kepada anak agar lebih menyenangkan.

Maksud dari pembangunan aplikasi ini adalah untuk memberikan solusi kepada pendidik dan orangtua yang merasa kesulitan dalam memberikan materi kosakata bahasa inggris kepada peserta didik. Aplikasi ini diharakan mampu menerapkan sistem belajar sambil bermain yang efektif untuk proses pembelajaran kepada anakanak. Sedangkan tujuan tujuan yang diharapkan dari pembangunan aplikasi ini adalah:

1. Menghasilkan aplikasi yang dapat meningkatkan pemahaman peserta didik mengenai materi tentang vocabulary dasar bahas Inggris dengan penerapan pembelajaran interaktif yang menyenangkan..

2. Menghasilkan aplikasi yang dapat membantu peserta didik dalam proses pembelajaran sekaligus sebagai alternatif media pembelajaran selain buku.

\section{ISI PENELITIAN}

\subsection{Metodologi Penelitian}

Metode yang digunakan dalam penelitian ini adalah metode penelitian Deskriptif, yaitu suatu metode dalam meneliti status sekelompok manusia, suatu obyek, suatu set kondisi, suatu sistem pemikiran, ataupun suatu kelas peristiwa pada masa sekarang. Tujuan dari penelitian deskriptif ini adalah untuk membuat deskripsi, gambaran atau lukisan secara sistematis, faktual dan akurat mengenai faktafakta, sifat-sifat hubungan antar fenomena yang diselidik.[3]

\subsection{Pembelajaran Berbasis Komputer}

Pembelajaran merupakan subset dari pendidikan sehingga keberadaan pembelajaran sungguh tidak dapat dinegasikan dalam dunia pendidikan. Pembelajaran bukanlah suatu yang terpisah atau bertentangan dengan pendidikan, melainkan sebuah hal yang terintegrasi dari proses pendidikan dan bahkan menjadi penentu utama keberhasilan pendidikan. Menurut Shoimatul (2013:62) pembelajaran adalah kegiatan guru secara terprogram dalam desain intruksional untuk membuat siswa belajar secara aktif, yang menekankan pada penyedian sumber belajar.
Pembelajaran ialah membelajarkan siswa menggunakan asas pendidikan dan teori belajar[2].

Pembelajaran berbasis komputer adalah pembelajaran yang menggunakan komputer sebagai alat bantu (Wena, 2011:203). Melalui pembelajaran ini bahan ajar disajikan melalui media komputer sehingga kegiatan proses belajar mengajar menjadi lebih menarik dan menantang bagi siswa.

Menurut Hick dan Hyde (dalam, Wena 2011:203) mengatakan bahwa dengan pembelajaran berbasis komputer siswa akan berinteraksi dan berhadapan langsung dengan komputer secara individual sehingga apa yang dialami oleh seorang siswa akan berbeda dengan apa yang dialami oleh siswa lain. Salah satu ciri yang paling menarik dari pembelajaran berbasis komputer terletak pada kemampuan berinteraksi secara langsung dengan siswa. Sedangkan menurut Warsita (2008:137) mengatakan bahwa pembelajaran berbasis komputer adalah salah satu media pembelajaran yang sangat menarik dan mampu meningkatkan motivasi belajar peserta didik.[5]

Jadi berdasarkan pendapat ahli di atas, dapat disimpulkan bahwa pembelajaran berbasis komputer adalah kegiatan belajar mengajar yang dilakukan oleh guru dengan komputer sebagai alat bantu guru dalam menyampaikan materi pembelajaran agar siswa tidak bosan dan termotivasi dalam mengikuti kegiatan pembelajaran yang sedang berlangsung di dalam kelas.

\subsection{Analisis Aplikasi Sejenis}

2.3.1 Pengenalan Aplikasi Edukasi Interaktif : Belajar bahasa Inggris anak.

Seri ini merupakan produk terbaru dari SENJA INC dengan nama: Belajar bahasa Inggris anak. Alikasi ini merupakan Game Edukasi pendidikan yang menyenangkan untuk anak-anak dari Paud hingga anak-anak Sd, yang dirancang sesuai dengan perkembangan otak anak. Aplikasi ini mengajarakan anak membaca huruf alfhabet $\mathrm{ABC}$ (A-Z) dan mengenalkan anggka (1-10) dalan bahasa Inggris beserta tatacara menulis yang disertai arah penulisan sehingga anak mengerti cara menulis yang benar. Berikut ini adalah tampilan menu pada Game Edukasi Anak : Belajar bahasa Inggris terlihat pada Tabel 1 
Tabel 1 Komponen Aplikasi SENJA INC

\begin{tabular}{|c|c|c|}
\hline \multicolumn{3}{|c|}{ Aplikasi English For Kids 1} \\
\hline No & Komponen & Keterangan \\
\hline 1 & Suara & $\begin{array}{l}\text { Digunakan sebagai pesan } \\
\text { penanda dalam pembelajaran }\end{array}$ \\
\hline 2 & Grafis & $\begin{array}{l}\text { Aplikasi ini memiliki bentuk } \\
\text { grafis } 2 \text { dimensi serta video } \\
\text { sebagai alat bantu } \\
\text { pembelajaran }\end{array}$ \\
\hline 3 & Menu & $\begin{array}{l}\text { Aplikasi ini terdiri dari } \\
\text { beberapa menu yang } \\
\text { memiliki fungsi beragam, } \\
\text { diantaranya : } \\
\text { a. Star (Alphabet, Number, } \\
\text { Flower, Fruit, Animal, } \\
\text { Color, Drink, Food, } \\
\text { Vehicle, School, } \\
\text { Geometry, House, } \\
\text { Cristmast, Country) } \\
\text { b. Videor streaming } \\
\text { (Alphabet, Number, } \\
\text { Flower, Fruit, Animal, } \\
\text { Color, Drink, Food, } \\
\text { Vehicle, School, } \\
\text { Geometry, House, } \\
\text { Cristmast, Country) } \\
\text { c. Loock and chose } \\
\text { d. Listen and guest } \\
\text { e. } \text { Quis }\end{array}$ \\
\hline 4 & Bahasa & $\begin{array}{l}\text { Bahasa Yang digunakan } \\
\text { adalah bahasa Inggris }\end{array}$ \\
\hline
\end{tabular}

\subsubsection{Pengenalan Aplikasi Edukasi Interaktif : English For Kids}

Seri ini merupakan produk terbaru yang ditawarkan oleh PVDAPPS dengan nama : English. Aplikasi ini merupakan Game Edukasi pendidikan yang menyenangkan untuk anak-anak yang dirancang sesuai dengan perkembangan anak. Aplikasi ini mengajarakan anak membaca huruf alfhabet ABC (A-Z), mengenalkan anggka (1-20), buah-buahan, hewan, warna, bendera negara, benda di lingkungan sekolah, makanan dan minuman dalam bahasa Inggris beserta quis untuk mengevaluasi pemahaman pengguna. Berikut ini adalah tampilan menu pada Game Edukasi Anak: English For Kids pada tabel.2.
Tabel 2 Komponen Aplikasi PVDAPPS

\begin{tabular}{|l|l|l|}
\hline \multicolumn{3}{|c|}{ Aplikasi Belajar Bahasa Inggris Anak } \\
\hline No & Komponen & Keterangan \\
\hline 1 & Suara & $\begin{array}{l}\text { Digunakan sebagai pesan } \\
\text { penanda dalam pembelajaran. }\end{array}$ \\
\hline 2 & Grafis & $\begin{array}{l}\text { Aplikasi ini memiliki bentuk } \\
\text { grafis 2 dimensi }\end{array}$ \\
\hline 3 & Menu & $\begin{array}{l}\text { Aplikasi ini terdiri dari } \\
\text { beberapa menu yang memiliki } \\
\text { fungsi beragam, diantaranya : } \\
\text { a. Alphabet } \\
\text { b. Angka } \\
\text { c. Writing Alfabet } \\
\text { d. Writing Angka }\end{array}$ \\
\hline 4 & Bahasa & $\begin{array}{l}\text { Bahasa yang digunakan dalam } \\
\text { aplikasi ini yaitu } \\
\text { menggunakan Bahasa Inggris }\end{array}$ \\
\hline
\end{tabular}

\subsubsection{Pengenalan Aplikasi Edukasi Interaktif : English For Kids}

Seri ini merupakan produk terbaru yang ditawarkan oleh Bamboomedi dengan nama : English For Kids. Bahasa Inggris adalah bahasa nomor satu di dunia, oleh karena itu wajib diajarkan kepada anak-anak sejak dini. Pembelajaran interaktid English For Kid adalah penunjang dasar dalam menguasai suatu bahasa dan memicu kreativitas anak mulai dari mengenal hurufn menyusun kata dan menyusun kalimat lengkap dengan cara membacadan terjemahanya dalam bahasa Indonesia sehinggha anak tidak mengalami kesulitan dalam menguasai bagasa Inggris. Berikut ini adalah tampilan menu pada Aplikasi Interaktif: English For Kids pada Tabel 3

Tabel 3 Komponen Aplikasi Bombomedia

\begin{tabular}{|l|l|l|}
\hline \multicolumn{3}{|c|}{ Aplikasi English For Kids 2 } \\
\hline No & Komponen & Keterangan \\
\hline 1 & Suara & $\begin{array}{l}\text { Suara digunakan sebagai pesan } \\
\text { penanda pembelajaran dan } \\
\text { backsong sebagai nada } \\
\text { pengiring aplikasi }\end{array}$ \\
\hline 2 & Grafis & $\begin{array}{l}\text { Aplikasi ini memiliki grafis 2D } \\
\text { beserta Animasi 2D }\end{array}$ \\
\hline 3 & Menu & $\begin{array}{l}\text { a. Alphabet } \\
\text { b. Word (Animal, Fruits, In } \\
\text { Home, } \\
\text { c. Sentence (in School, In } \\
\text { home, Food and drink) }\end{array}$ \\
\hline 4 & Bahasa & $\begin{array}{l}\text { Bahasa yang digunakan adalah } \\
\text { Bahasa Inggris }\end{array}$ \\
\hline
\end{tabular}

Dari observasi yang telah dilakukan terhadap 3 aplikasi Edukasi Interaktif Anak tersebut maka dapat diambil beberapa kesimpulan diantaranya adalah sebagai berikut : 
1. Aplikasi Edukasi Interaktif anak : Belajar bahasa Inggris anak memiliki komponen multimedia berupa suara (audio) sebagai pesan untuk pembelajaran dan bentuk grafis 2 dimensi dengan warna yang menarik. Kemudian memiliki menu Alfabet untuk pembelajaran jenis hurus, Angka untuk pembelajaran mengenal angka dari 1-10, Writing Alphabet untuk belajar menulis huruf dan Writing Angka untuk belajar menulis angka.

2. Aplikasi Edukasi English For Kids 1 memiliki komponen multimedia berupa pesan suara (audio) sebagai pesan untk pembelajaran dan mempunyai desain grafis 2 dimensi yang tidak disertai dengan warna yang menarik. Kemudian disertai banyak menu pembelajar diantaranya : menu belajar Alphabet yang mengenalkan huruf dari A-Z, Number yang mengenalkan angka dari 1-10, Flower yang mengenalkan 18 jenis bunga, Fruit yang mengenalkan 20 jenis buah-buahan, Animal yang mengenalkan 20 jenis hewan, Color yang mengenalkan 11 warna dasar, Drink yang mengenalkan 9 jenis miniman, Food yang mengenalkan 9 jenis makanan, Vehicle yang mengenalkan 9 jenis kendaraan, School yang menjelaskan 10 jenis benda yang ada di sekitar sekolah, Geometry yang mengenalkan 5 jenis bangun ruang, House yang mengenalkan 12 jenis benda yang disekitar rumah, Cristmast yang mengenalkan benda komponen hari natal, Country yang mengenalkan 27 lambang negara di dunia, yang disertai live video streaming. Menu latihan terdapat dua jenis permainan diantaranya tebak kata yang disertai soal dengan suara dan tebak gambar dengan cara menginputkan nama gambar tersebut menggunakan bahasa Inggris. Untuk metode penilaiyan anggka terbesar adalah pion 100. Sedangkan untuk bahasa Aplikasi ini menggunkan bahasa Inggris.

3. Aplikasi Edukasi English For Kids 2 memiliki komponen backsong suara sebagai pengiring pembelajaran serta suara (audio) pesan pembelajaran dan mempunyai desaiin grafis 2 dimensi disertai animasi serta warna yang menarik. Mempunyai satu menu pembelajaran yaitu alphabet sedangkan untuk menu animals, fruits in home, in school food \& drink cenderung bersifat kepada permainan tebak kata yang masing masih tiap menu mengenalkan 5 objek. Adapun bahasa yang digunakan adalah bahasa inggris dan bahasa Indonesia dimana bahasa Inggris dijadikan sebagai pesan media pembelajaran sedangkan bahasa Indonesia dijadikan pengantar masuk menu.

\subsection{Komponen Aplikasi Yang akan Dibangun Pada Aplikasi Ayo Belajar Bahasa Inggris}

Pada table 4 akan dijelaskan tentang komponen-komponen yang terdapat pada aplikasi ayo belajar bahasa Inggris untuk Anak ini.

\section{Tabel 4 Komponen Aplikasi Ayo Belajar Bahasa Ingris Yang Akan Dibangun}

\begin{tabular}{|c|c|c|}
\hline No & Komponen & Keterangan \\
\hline 1 & Suara & $\begin{array}{l}\text { a. Digunakan sebagai media } \\
\text { interaksi yang akan } \\
\text { memandu setiap jalannya } \\
\text { permainan. } \\
\text { b. Digunakan sebagai pesan } \\
\text { penanda ketika benar dan } \\
\text { salah pada bagian } \\
\text { permainan. } \\
\text { c. Digunakan sebagai efek } \\
\text { suara animasi-animasi } \\
\text { pada permainan. }\end{array}$ \\
\hline 2 & Grafis & $\begin{array}{l}\text { Aplikasi ini memiliki bentuk } \\
\text { grafis } 2 \text { dimensi }\end{array}$ \\
\hline 3 & Menu & $\begin{array}{l}\text { Aplikasi ini terdiri dari } \\
\text { beberapa menu yang } \\
\text { memiliki fungsi beragam, } \\
\text { diantaranya : } \\
\text { a. Belajar ; Sendiri, } \\
\text { Otomatis ( Warna Huruf, } \\
\text { Angka, Buah-buahan, } \\
\text { Hewan dan Benda) } \\
\text { b. Latihan ; Warna, Huruf, } \\
\text { Angka, Buah-buahan } \\
\text { Hewan dan Benda } \\
\text { c. Menu Kamus } \\
\text { d. Menu Evaluasi } \\
\text { e. Menu Tentang }\end{array}$ \\
\hline 4 & Score & $\begin{array}{l}\text { Sistem score/penilaian hanya } \\
\text { terdapat pada bermain } \\
\text { Evaluasi }\end{array}$ \\
\hline 5 & Bahasa & $\begin{array}{l}\text { Untuk menu bahasa yang } \\
\text { digunakan dalam aplikasi ini } \\
\text { adalah bahasa Indonesia dan } \\
\text { bahasa Inggris, sedangkan } \\
\text { untuk pesan pembelajaran } \\
\text { menggunakan bahasa Inggris }\end{array}$ \\
\hline
\end{tabular}

\subsection{Spesifikasi Kebutuhan Perangkat Lunak}

Berdasarkan dari analisis masalah, analisis sistem, dan analisis aplikasi sejenis dapat didapat spesifikasi kebutuhan perangkat lunak. Spesifikasi kebutuhan perangkat lunak yang akan dibangun 
Vol. 8, No. 1, Maret 2019, ISSN : 2089-9033, eISSN : 2715-7849

dibagi menjadi dua kebutuhan yaitu sfesifikasi kebutuhan nonfungsional dan spesifikasi kebutuhan fungsional. dapat dilihat pada Tabel 5 dan Tabel .6.

Tabel 5 Tabel Keputuhan Nonfungsional

\begin{tabular}{|l|l|}
\hline Kode SKPL & $\begin{array}{l}\text { Sfesifikasi Kebutuhan } \\
\text { Perangkat Lunak }\end{array}$ \\
\hline SKPL-NF-001 & $\begin{array}{l}\text { Sistem yang akan dibangun } \\
\text { adalah aplikasi mobile }\end{array}$ \\
\hline SKPL-NF-002 & $\begin{array}{l}\text { Sistem mobile yang dibangun } \\
\text { berjalan pada platfom android }\end{array}$ \\
\hline SKPL-NF-003 & $\begin{array}{l}\text { Sistem mobile yang dibangun } \\
\text { dijalankan pada sistem oprasi } \\
\text { minimal android gingerbred }\end{array}$ \\
\hline SKPL-NF-004 & $\begin{array}{l}\text { Sistem yang dibangun dengan } \\
\text { spesifikasi hardware yang } \\
\text { memenuhi standar kebutuhan }\end{array}$ \\
\hline
\end{tabular}

Berikut ini adalah tabel kebutuhan fungsional aplikasi ayo belajar bahasa Inggris

Tabel 6 Tabel Kebutuhan Fungsional

\begin{tabular}{|c|c|}
\hline Kode SKPL & $\begin{array}{ll}\text { Sfesifikasi } & \text { Kebutuhan } \\
\text { Perangkat Lunak } & \\
\end{array}$ \\
\hline SKPL-F-001 & $\begin{array}{l}\text { Sistem menyediakan fungsi } \\
\text { untuk mengambil data pengguna }\end{array}$ \\
\hline SKPL-F-002 & $\begin{array}{lcr}\text { Sistem } & \text { menyediakan } & \text { fungsi } \\
\text { untuk melakukan } & \text { animasi } \\
\text { slideshow } & \text { model } & \text { belajar } \\
\text { Otomatis } & & \\
\end{array}$ \\
\hline SKPL-F-003 & $\begin{array}{l}\text { Sistem menyediakan fungsi } \\
\text { untuk melakukan model metode } \\
\text { belajar manual }\end{array}$ \\
\hline SKPL-F-004 & $\begin{array}{l}\text { Sistem menyediakan fungsi } \\
\text { untuk melakukan mulai belajar } \\
\text { mengenal warna }\end{array}$ \\
\hline SKPL-F-005 & $\begin{array}{l}\text { Sistem menyediakan fungsi } \\
\text { untuk melakukan mulai belajar } \\
\text { mengenal angka }\end{array}$ \\
\hline SKPL-F-006 & $\begin{array}{l}\text { Sistem menyediakan fungsi } \\
\text { untuk melakukan mulai belajar } \\
\text { mengenal huruf }\end{array}$ \\
\hline SKPL-F-007 & $\begin{array}{l}\text { Sistem menyediakan fungsi } \\
\text { untuk melakukan mulai belajar } \\
\text { mengenal buah-buahan }\end{array}$ \\
\hline SKPL-F-008 & $\begin{array}{l}\text { Sistem menyediakan fungsi } \\
\text { untuk melakukan mulai belajar } \\
\text { mengenal hewan }\end{array}$ \\
\hline SKPL-F-009 & $\begin{array}{l}\text { Sistem menyediakan fungsi } \\
\text { untuk melakukan mulai belajar } \\
\text { mengenal benda }\end{array}$ \\
\hline SKPL-F-010 & $\begin{array}{l}\text { Sistem menyediakan fungsi } \\
\text { untuk memulai mengerjakan } \\
\text { latihan warna }\end{array}$ \\
\hline SKPL-F-011 & $\begin{array}{l}\text { Sistem menyediakan fungsi } \\
\text { untuk memulai mengerjakan } \\
\text { latihan angka }\end{array}$ \\
\hline
\end{tabular}

\begin{tabular}{|l|l|}
\hline SKPL-F-012 & $\begin{array}{l}\text { Sistem menyediakan fungsi } \\
\text { untuk memulai mengerjakan } \\
\text { latihan huruf }\end{array}$ \\
\hline SKPL-F-013 & $\begin{array}{l}\text { Sistem menyediakan fungsi } \\
\text { untuk memulai mengerjakan } \\
\text { latihan buah-buahan }\end{array}$ \\
\hline SKPL-F-014 & $\begin{array}{l}\text { Sistem menyediakan fungsi } \\
\text { untuk memulai mengerjakan } \\
\text { latihan hewan }\end{array}$ \\
\hline SKPL-F-015 & $\begin{array}{l}\text { Sistem menyediakan fungsi } \\
\text { untuk memulai mengerjakan } \\
\text { latihan benda }\end{array}$ \\
\hline SKPL-F-016 & $\begin{array}{l}\text { Sistem menyediakan fungsi } \\
\text { untuk memulai pencarian arti } \\
\text { kata }\end{array}$ \\
\hline SKPL-F-017 & $\begin{array}{l}\text { Sistem menyediakan fungsi bagi } \\
\text { pengguna untuk mengerjakan } \\
\text { soal evaluasi serta mendapatkan } \\
\text { hasil nilai }\end{array}$ \\
\hline
\end{tabular}

\subsection{Use Case}

Use Case Diagram merupakan bagian dari fungsional yang dimiliki sistem yang akan mendeskripsikan interaksi antara satu aktor dengan sistem yang akan dibagun. Berikut ini adalah Use Case diagram Aplikasi Edukasi Interaktif Ayo Belajar Bahasa Inggris Berbasis Platform Android

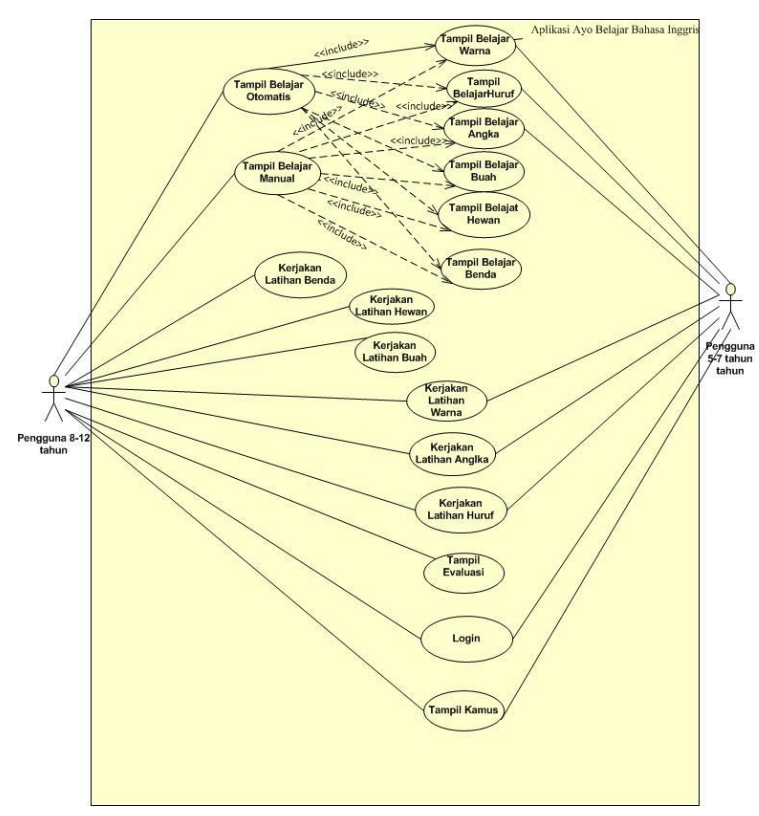

Gambar 1 Use Case Diagram

\subsection{Class Diagram}

Class diagram digunakan untuk menggambarkan struktur sistem dari segi pendefinisian kelas-kelas. Class diagram memberikan gambaran sistem secara ystatis dan relasi antar mereka. Class diagram dari aplikasi ayo 
belajar bahasa Inggris ini dapat dilihat pada gambar 2

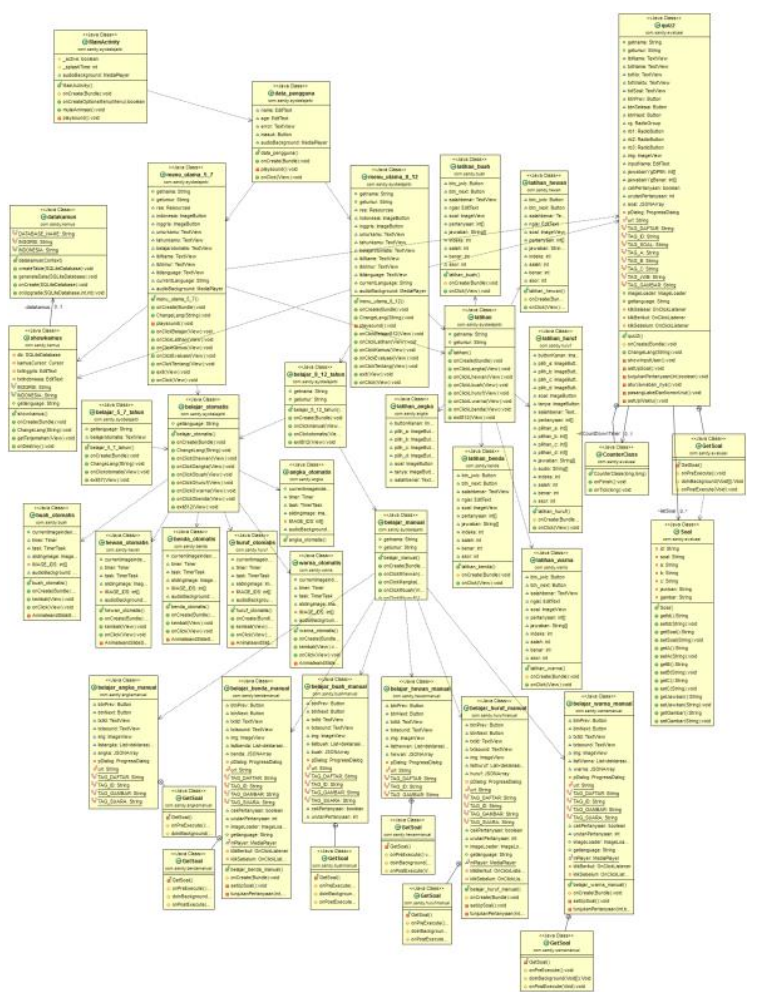

Gambar 2 Class Diagram

\subsection{Struktur Menu}

Perancangan arsitektur menyediakan gambaran dari stuktur menu program dari perangkat lunak yang akan dibuat. Berikut adalah gambaran perancangan arsitektural menu pada Aplikasi Ayo Belajar Bahasa Iggris Berbasis Platform Android.

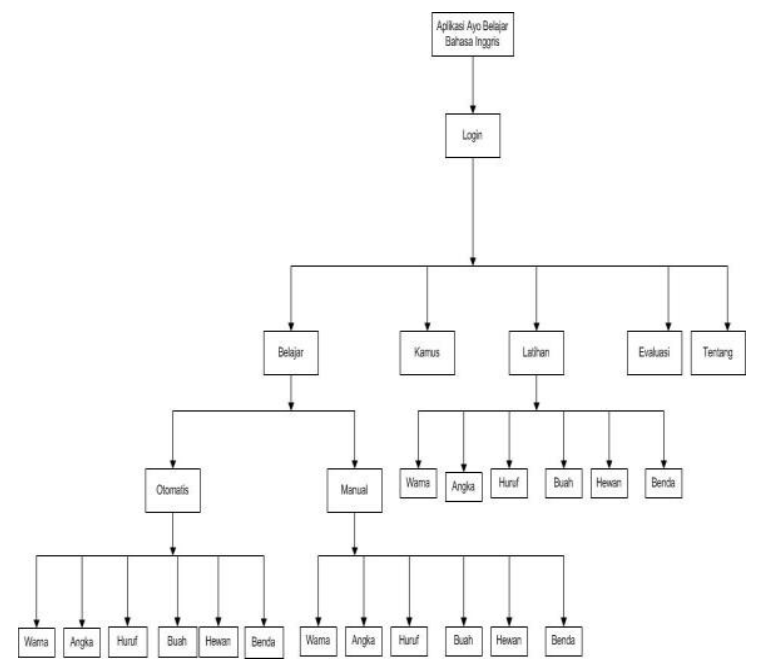

Gambar 3 Struktur Menu

\subsection{Kesimpulan Hasil Pengujian Alpha}

Berdasarkan hasil pengujian alpha yang telah dilakukan maka dapat ditarik kesimpulan bahwa fungsionalitas dari aplikasi Ayo Belayar Bahasa Inggris untuk anak ini telah sesuai dengan rencana awal dan fungsionalitas sudah berjalan secara maksimal, tetapi dalam ranah intelekteual selalu terbuka ruang untuk koreksi dan pengembangan ke tahap yang lebih baik, karena tidak menutup kemungkinan dapat terjadi kesalahan pada saat aplikasi digunakan baik kesalahan dari aplikasi itu sendiri atau kesalahan pengguna dan kesalahankesalahan lainya. Sehingga membutuhkan perawatan untuk menjaga aplikasi agar tetap berjalan sesuai dengan yang diharapkan.

\subsection{Pengujian Beta}

Pengujian beta merupakan pengujian yang bersifat objektif yang mana pengujian ini dilakukan langsung dengan empiris di lapangan, yang bertujuan untuk mengetahui sejauhmana kulaitas sistem. Pengujian beta dilakukan dengan penelitian kepada calon pengguna aplikasi. Teknik pengumpulan dala dilakukan melalui kuisioner oleh pembangun kepada pengguna yang terdiri dari 30 orang peserta didik.

Untuk mengetahui sejauhmana tanggapan dan penilaian pengguna terhadap Aplikasi Ayo Belajar Bahasa Inggris ini telah dilakukan kuisioner kepada responden, kemudian dilakukan perhitungan dengan denga menggunakan skala likert dimana data dianalisis dengan menghitung rata-rata jawaban berdasarkan skoring terhadap jawaban dari responden.

Kuesioner merupakan daftar pertanyaan yang akan digunakan oleh peneliti untuk memperoleh data dari sumbernya secara langsung melalui proses komunikasi atau dengan mengajukan pertanyaan.

a. Untuk menghitung data hasil kuisioner diberikan 5 pilihan jawaban dan skornya, dengan ketentuan dapat dilihat pada tabel 7.

Tabel 7 Skala Jawaban Kuisioner

\begin{tabular}{|l|l|l|}
\hline \multicolumn{1}{|c|}{ Inisial } & \multicolumn{1}{c|}{ Jawaban } & \multicolumn{1}{c|}{ Skor } \\
\hline YSS & Ya Sangat Setuju & 5 \\
\hline S & Setuju & 4 \\
\hline BS & Biasa Saja & 3 \\
\hline KS & Kurang Setuju & 2 \\
\hline TS & Tidak Setuju & 1 \\
\hline
\end{tabular}

b. Untuk mencari nilai persentase dari masing-masing jawaban kuesioner digunakan rumus skala likert sebagai berikut: 


$$
P=\frac{s}{\text { Skor ideal }} \times 100 \%
$$

Keterangan :

$\mathrm{P}=$ Nilai persentase yang dicari $\mathrm{S}=$ Jumlah frekuensi dikalikan dengan nilai yang di tetapkan jawaban.

Skor ideal $=$ Nilai tertinggi dikalikan dengan jumlah sampel

\section{Tabel 8 Interpretasi Hasil Perhitungan}

\begin{tabular}{|l|l|}
\hline \multicolumn{1}{|c|}{ Nilai } & \multicolumn{1}{c|}{ Keterangan } \\
\hline $0 \%-20 \%$ & Ya Sangat Setuju \\
\hline $20 \%-40 \%$ & Setuju \\
\hline $41 \%-60 \%$ & Biasa saja \\
\hline $61 \%-80 \%$ & Kurang Setuju \\
\hline $81 \%-100 \%$ & Sangat Setuju \\
\hline
\end{tabular}

\subsection{Data kuisioner}

Adapun data kuisioner dari aplikasi ayo belajar bahasa Inggris untuk anak ini adalah sebagai berikut:

1. Jumlah responden yang terdiri dari 30 orang yang terdiri peserta didik yang ada di Lembaga Kursus dan Pelalihan LIEBE.

2. Point yang menjadi bahan penilaian adalah:

a. Membantu peserta didik untuk meningkatkan pemahaman mengenai kosakata Bahasa Inggris secara mandiri.

b. Membantu memudahkan peserta didik dalam proses pembelajaran sekaligus sebagai alternatif media pembelajaran selain buku.

Berikut adalah daftar pertanyaan kepada pengguna pada tabel 9 .

Tabel 9 Daftar Pertanyaan Kuisioner

\begin{tabular}{|l|l|}
\hline Pengguna & \multicolumn{2}{|c|}{ Pertanyaan } \\
\hline Pengguna & 1. $\begin{array}{l}\text { Menurut anda, apakah aplikasi ini } \\
\text { memberikan kemudahan dalam } \\
\text { dalam proses mempelajari } \\
\text { kosakata bahasa Inggris? }\end{array}$ \\
\cline { 2 - 3 } & $\begin{array}{l}\text { 2. } \\
\text { benurut anda, apakah minat } \\
\text { belajar anda meningkat setelah } \\
\text { menggunakan aplikasi ini? }\end{array}$ \\
\cline { 2 - 3 } & $\begin{array}{l}\text { Menurut anda, apakah } \\
\text { pemahaman anda mengalami } \\
\text { peningkatan setelah belajar } \\
\text { menggunakan aplikasi ini? }\end{array}$ \\
\cline { 2 - 3 } & 4. $\begin{array}{l}\text { Menurut anda, apakah aplikasi ini } \\
\text { dapat mengajak belajar secara }\end{array}$ \\
\hline
\end{tabular}

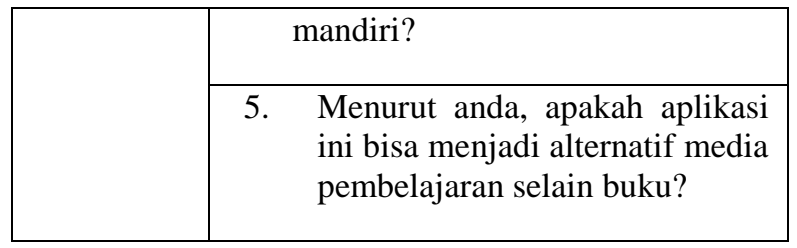

Berikut adalah hasil pengumpulan data dari masing-masing jawaban untuk setiap pengguna. Jawaban dari masing-masing responden.

Untuk melihat sikap responden secara keseluruhan terhadap kualitas aplikasi ayo belajar bahasa inggris untuk anak berbasis platform android, langkah - langkahnya adalah :

1. Menentukan skor maksimal, yaitu skor maksimal yang diperoleh tiap responden dikali banyaknya responden. $(25 \times 30=750)$

2. Menentukan skor minimal, yaitu skor minimal yang diperoleh tiap responden dikali banyaknya responden. $(5$ x $30=150)$

3. Menentukan nilai median, yaitu hasil penjumlahan total skor maksimal dengan total skor minimal dibagi dua. $(750+150): 2=450$

4. Menentukan nilai kuartil 1, yaitu hasil penjumlahan total skor minimal dengan median dibagi dua. $(150+450): 2=300$

5. Menentukan nilai kuartil 3, yaitu hasil penjumlahan skor maksimal dengan median dibagi dua. $(750+450): 2=600$

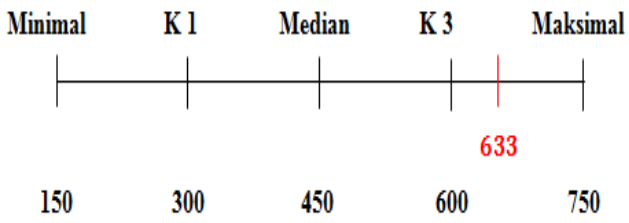

\section{Gambar 4 Hasil Pengolahan Kuesioner Responden keseluruhan}

Tabel 10 Kategori sikap keseluruhan

\begin{tabular}{|l|l|c|}
\hline $\begin{array}{l}\text { Sikap Sangat } \\
\text { Positif }\end{array}$ & $\begin{array}{l}\text { Kuartil 3 } \leq \mathrm{x} \leq \text { Skor } \\
\text { Maksimal }\end{array}$ & $600-750$ \\
\hline Sikap Positif & Median $\leq \mathrm{x}<$ Kuartil 3 & $450-600$ \\
\hline Sikap Negatif & Kuartil 1 $\mathrm{x}<$ Median & $300-450$ \\
\hline $\begin{array}{l}\text { Sikap Sangat } \\
\text { negatif }\end{array}$ & $\begin{array}{l}\text { Skor Minimal } \leq \mathrm{x}< \\
\text { Kuartil 1 }\end{array}$ & $150-300$ \\
\hline
\end{tabular}

Berdasarkan gambar di atas maka secara keseluruhan sikap responden pada aplikasi ayo belajar bahasa inggris untuk anak bebasis platform android ada pada kategori sikap sangat positif. Hal ini ditunjukkan oleh skor total responden yang terletak antara skor Kuartil 3 dengan Maksimal, yang merupakan batas skor pada kategori sikap sangat positif. Artinya bahwa secara keseluruhan responden memandang aplikasi ini sangat berguna dan membantu meningkatkan pemahaman peserta 
didik serta mamu merangsang anak agar dapat belajar secara mandiri.

\section{PENUTUP}

Hasil yang diperoleh dari penelitian yang dilakukan dalam penyusunan skripsi ini serta mengacu pada tujuan penelitian maka diperoleh kesimpulan.

1. Aplikasi ini dapat meningkatkan pemahaman peserta didik mengenai materi tentang vocabulary dasar bahas Inggris dengan penerapan pembelajaran interaktif yang menyenangkan..

2. Aplikasi ini dapat membantu peserta didik dalam proses pembelajaran sekaligus sebagai alternatif media pembelajaran selain buku.

Terdapat beberapa saran ataupun kritik yang dapat dijadikan referensi untk pengembangan aplikasi ayo belajar bahasa Inggris, agar dapat mengembangkan aplikasi ayo belajar bahasa Inggris untuk anak dengan menggunakan API Google Translate agar kapasitas kata dalam kamus lebih lengkap, menambah modul materi tense dan grammar serta menambahkan animasi video interaktif untuk menarik minat belajar anak.

Demikianlah saran yang dapat diberikan, semoga saran tersebut dapat dijadikan bahan masukan yang ingsyallah dapat bermanpaat bagi masyarakat yang ingin mengembangkan aplikasi ini. Karena bagaimanupun dalam ranah intelektual selalu ada ruang kritik untuk menjadikanya karya yang lebih besar.

\section{DAFTAR PUSTAKA}

.1. Harun Rasyid. 2009. Mansyur \& Suranto. Asesmen Perkembangan Anak Usai Dini. Yogyakarta : Multi Presindo.

2. Ula. S. Shoimatul. 2013. Revolusi Belajar. Yogyakarta: Ar-Ruzz Media.

3. R Sugiyono. 2011. Metode Penelitian Kuantitatif, kualitatif dan $R \& D$. Bandung: Alfabeta.

4. A.S. Rosa. 2013. Shalahudin M. Rekayasa Perangkat Lunak Terstruktur dan Berorientasi Objek. Bandung : Informatika.

5. Rusman. 2013. Belajar dan Pembelajaran Berbasis Komputer. Bandung: ALFABETA.

6. Sigit, dkk. 2008. Pengembangan Pembelajaran dengan menggunakan Multimedia Interaktif Untuk Pembelajaran yang Berkualitas. Karya Tulis Ilmiah. Universitas Negeri semarang

7. Safaat, N. H. 2012. Pemrograman Aplikasi Mobile Smartphone dan Tablet PC Berbasis Android. Bandung: Informatika. 